\title{
Corporate governance and payment systems operators: a study in Brazil and the united kingdom based on recommendations of the committee on payments and market infrastructures
}

Leonardo Backes Pilla' - Universidade de Brasília

Carlos André de Melo Alves² - Universidade de Brasília - Departamento de Administração

ABSTRACT The main objective of this study is to investigate the corporate governance characteristics of payment systems operators in Brazil and the United Kingdom, based on recommendations of the Committee on Payments and Market Infrastructure - CPMI. This study is descriptive, with a qualitative approach, using both bibliographical and documental research. We analyzed bylaws and other documents collected in August of 2015 of four payment systems operators intentionally selected from Brazil and the United Kingdom. In order to analyze the presence or absence of corporate governance characteristics of each payment system operator, we employed content analysis, considering a checklist composed of 20 key elements distributed along 7 key considerations based on the CPMI's international recommendations for corporate governance. Data analysis also employed binomial statistic tests. The main results of 80 key elements' analyses show that, in general, 65\% of these key elements are present in the payment systems operators' documents analyzed. The proportion of key elements present or absent is not equally distributed between key considerations. This study can bring corporate governance insights to academics and others stakeholders involved in the improvement of operation, regulation and supervision of payment systems, mainly in Brazil and the United Kingdom.

Keywords: Payment Systems. CPMI Recommendations. Corporate Governance. Brazil. United Kingdom. 


\section{INTRODUCTION}

Efficient payment systems are crucial for the proper working of financial markets, reducing the cost and the risk of the transactions of goods and services in an economy. By the same logic, an ineffective payment system arrangement can bring various undesired effects, such as inefficient use of financial resources, financial losses and even a reduction in the capacity of economic development (CIRASINO; GARCIA, 2008). Given the importance that payment systems have to the various participants in the financial markets, there is a lack of recent academic studies having these systems operators as their main focus.

The need to establish international standards and principles to promote the safety and efficiency of payment systems led to the creation of the Committee on Payments and Market Infrastructure - CPMI ${ }^{1}$. The CPMI is part of the Bank for International Settlements, and it contains representatives of $24 \mathrm{di}$ fferent countries (CPMI, 2014a), including Brazil and the United Kingdom. By definition, payment systems are one type of existing financial market infrastructures (CPSS-IOSCO, 2012a). In 2012, the CPSS-IOSCO published a report outlining the key principles to be followed by the financial market infrastructures - FMIs ${ }^{2}$, including the Corporate Governance principle. These principles and other recommendations of the CPMI can serve as a framework for analysis of payment systems of different countries or jurisdictions,

The main objective of this study is to investigate the corporate governance characteristics of payment systems operators in Brazil and the United Kingdom, based on recommendations of the CPMI. This study is descriptive, with a qualitative approach, covering both bibliographical and documental research. This is a relevant study because the analysis considers comparisons between payment systems operators from Brazil and the United Kingdom. These payment systems operators were selected for being in different countries and because they both participate in the CPMI.

1. The CPMI acts as a forum for cooperation between Central Banks in the definition of policy, supervision and operational matters for payment systems and financial market infrastructures (CPMI, 2014a). Before September 2013, the CPMI was known as 'Committee on Payments and Settlement and Systems' - CPSS. The change of name became effective as of 1 September 2014 (BIS, 2016). For the purposes of this study, CPMI and CPSS are synonyms.

2. Financial Market Infrastructures can be defined as "a multilateral system among participating institutions, including the operator of the system, used for the purposes of clearing, settling or recording payments, securities, derivatives, or other financial transactions" (CPSS-IOSCO, 2012a, p.7). 
Additionally, this research differs of others because it employs principles and recommendations about corporate governance to allow data comparability of payment system operators in an international framework. Finally, this study can bring corporate governance insights to academics and others stakeholders involved in the improvement of operation, regulation and supervision of payment systems, mainly in Brazil and the United Kingdom.

\section{LITERATURE REVIEW}

\subsection{Payment systems}

According to the CPSS-IOSCO (2012a, p.8), a payment system is a "set of instruments, procedures, and rules for the transfer of funds between or among participants; the system includes the participants and the entity operating the arrangement". The transfer of funds is settled in an agreed operational infrastructure.

Payment systems can be classified by the manner in which they settle payments: either by using a real-time gross settlement (RTGS) or a multilateral deferred net settlement (DNS) mechanism. RTGS systems process transactions in a continued manner, which means the balance of the participating institutions is updated after each transaction, greatly reducing credit and liquidity risks. On the other hand, DNS systems settle all transactions between participants by their net amount in a pre-determined moment, usually at the end of the business day (CPSS-IOSCO, 2012a).

Payment systems can also be classified by their average payment value. Systems which typically process a large volume of low value payments are classified as retail payment systems. These retail payment systems will settle payments either by RTGS or DNS. On the other hand, large-value payment systems process large value and high priority payments, and settle payments via RTGS (CPSS-IOSCO, 2012a).

Regardless of the country in which a payment system works, it is recommended adherence to the international principles that are applicable to payment systems. These principles include the Core Principles for Systematically Important Payment Systems (CPSS, 2001) and the Principles for Financial Market Infrastructures (CPSS-IOSCO, 2012a). 
The core principles were elaborated on a report published in 1998 with the central banks of the member states of the G10 and various other financial representatives from other countries. The report established a consensus on the ten principles the systematically important payment systems should follow. Typically, systematically important payment systems are those that have the potential to cause a systemic collapse (CPSS, 2001).

The principles for financial market infrastructures were published by the CPSS-IOSCO (2012a) and developed in a manner that they could be applicable to the five types of financial market infrastructures: payment systems, central securities depositories, securities settlement systems, central counterparties and trade repositories. The Frame 1 demonstrates what principles are applicable to each type of financial market infrastructure.

Frame 1 - Applicability of the principles for the specific type of market infrastructures.

\begin{tabular}{|c|c|}
\hline MARKET INFRASTRUCTURE TYPE & APPLICABLE PRINCIPLES \\
\hline Payment systems & 1 to 5,7 to $9,12,13,15$ to 19,21 to 23 \\
\hline Central securities depositories & 1 to $3,10,11,13,15$ to 23 \\
\hline Securities settlement systems & 1 to 5,7 to $10,12,13,15$ to 23 \\
\hline Central counterparties & 1 to 10,12 to 23 \\
\hline Trade repositories & 1 to $3,15,17$ to 24 \\
\hline
\end{tabular}

Source: adapted from CPSS-IOSCO (2012a).

Legend: 1. Legal basis 2. Governance 3. Framework for the comprehensive management of risks 4. Credit risk 5. Collateral 6. Margin 7. Liquidity risk 8. Settlement finality 9. Money settlements 10. Physical deliveries 11. Central securities depositories 12. Exchange-of-value settlement systems 13. Participant-default rules and procedures 14 . Segregation and portability 15 . General business risk 16. Custody and investment risks 17. Operational risk 18. Access and participation requirements 19. Tiered participation arrangements 20. FMI links 21. Efficiency and effectiveness 22. Communication procedures and standards 23. Disclosure of rules, key procedures, and market data 24 . Disclosure of market data by trade repositories. 
The CPSS-IOSCO (2012a) recommends that the principles be adopted and implemented in an integrated manner, as they complement each other. As shown in the Frame 1, some of the principles are applicable to specifically one type of infrastructure, such as principle eleven. The focus of this study, however, will be the second principle, governance, applicable to payment systems. Aspects of corporate governance related to payment systems will be shown in Section 2.2.

\subsection{Corporate governance and payment systems}

The Organisation For Economic Co-operation and Development - OECD defines corporate governance as it follows:

A set of relationships between a company's management, its board, its shareholders and other stakeholders. Corporate governance also provides the structure through which the objectives of the company are set, and the means of attaining those objectives and monitoring performance are determined (OECD, 2015, p.9).

The different approaches to corporate governance can be classified in two groups: the first one (shareholder approach) is more centred towards the rights and interests of the shareholder. On the other hand, the second group (stakeholder approach) concerns itself in assuming commitments with stakeholders, which can be internal such as employees, external such as clients and suppliers or even its surroundings, like the community, government and the environment (ANDRADE; ROSSETTI, 2004).

The Brazilian Institute for Corporate Governance - BICG, in its Code of Best Practices for Corporate Governance, states that the board of directors is the main component of the corporate governance system (BICG, 2009). The board of directors can establish the vision, values and strategy for the organisation, which are then transmitted to the management. Management is the body that consolidates the decision making process in the organisation, and some of its functions are the administrative tasks, organisation, direction, human resources management and performance evaluation (OLIVEIRA, 2015). 
The corporate governance principles can also be studied in a perspective of payment systems recommendations. In 2012, the CPSS elaborated principles, as mentioned in Section 2.1, for systematically important payment systems. Principle ten of the CPSS (2001, p. 53) states that "the system's governance arrangements should be effective, accountable and transparent". The report specifies that the effective implementation of the principle does not depend in the arrangement format themselves, which could even be covered by specific legislation, but does so by the results they generate (CPSS, 2001). Later, the CPSS-IOSCO (2012a) expands the applicability of the governance principle from payment systems to market infrastructures. It also expands its definition:

An FMI should have governance arrangements that are clear and transparent, promote the safety and efficiency of the FMI, and support the stability of the broader financial system, other relevant public interest considerations, and the objectives of relevant stakeholders (CPSS-IOSCO, 2012a, p.1).

It must be noted that for the purpose of this research, the applicability of the governance principle will consider payment system operators. It is not the system itself that will have governance arrangements, but its controlling operator. This is a key aspect since, in practical terms, there could be one operator controlling more than one payment system.

The CPMI also publishes a document used to assess the disclosure of the financial market infrastructure principles. For the principle of governance, the document presents 20 key elements distributed in 7 key considerations (Frame 2). These key elements and key considerations, based on the corporate governance principle of CPMI, can be used as a framework for analysis of corporate governance characteristics of payment systems operators of different countries, including Brazil and the United Kingdom. 
Frame 2 - Key considerations and key elements based on the governance principle.

\begin{tabular}{|c|c|}
\hline KEY CONSIDERATION & KEY ELEMENT \\
\hline \multirow{3}{*}{ 1. Objectives } & 1. Identification of the FMls objectives. \\
\hline & 2. Prioritisation of safety and efficiency in the FMl's objectives. \\
\hline & $\begin{array}{l}\text { 3. Explicit support for financial stability and other relevant public interests in the } \\
\text { FMI's objectives. }\end{array}$ \\
\hline \multirow{3}{*}{$\begin{array}{l}\text { 2. Lines of responsibility } \\
\text { and accountability }\end{array}$} & $\begin{array}{l}\text { 4. Identification of the governance arrangements under which the board and } \\
\text { management operate. }\end{array}$ \\
\hline & 5. Identification of lines of responsibilities and accountability within the FMI. \\
\hline & 6. Disclosure of the identified governance arrangements. \\
\hline \multirow{4}{*}{ 3. Board of directors } & $\begin{array}{l}\text { 7. Identification of the roles and responsibilities of the FMI's board of directors (or } \\
\text { equivalent). }\end{array}$ \\
\hline & 8. Identification of procedures for the functioning of the board. \\
\hline & $\begin{array}{l}\text { 9. Identification of processes to identify, address, and manage conflicts of interest } \\
\text { of members. }\end{array}$ \\
\hline & 10. Review of board's performance. \\
\hline \multirow{3}{*}{ 4. Directors } & 11. Identification of the appropriate skill sets for board members. \\
\hline & 12. Identification of appropriate incentives for board members. \\
\hline & 13. Inclusion of non-executive board members. \\
\hline \multirow{2}{*}{ 5. Management } & 14. Identification of the roles and responsibilities of the FMI's management. \\
\hline & 15. Identification of skills, experience and integrity of management. \\
\hline \multirow{3}{*}{ 6. Risk Management } & 16. Identification of the risk-management framework established by the board. \\
\hline & $\begin{array}{l}\text { 17. Identification of board processes to determine, endorse, and regularly review } \\
\text { the risk-management framework. }\end{array}$ \\
\hline & $\begin{array}{l}\text { 18. Identification of authority, independence, resources, and access to the board of } \\
\text { the risk-management and internal control functions in governance arrangements. }\end{array}$ \\
\hline \multirow[t]{2}{*}{ 7. Stakeholders } & $\begin{array}{l}\text { 19. Identification of how the legitimate interests of direct and indirect participants } \\
\text { and other relevant stakeholders are reflected in the FMI's design, rules, strategy, } \\
\text { and major decisions. }\end{array}$ \\
\hline & $\begin{array}{l}\text { 20. Identification of how the FMI discloses major decisions to relevant stakeholders } \\
\text { and, where appropriate, the public. }\end{array}$ \\
\hline
\end{tabular}

Source: Adapted from CPSS-IOSCO (2012b). 
Finally, it is relevant to state that the payment system regulators from United Kingdom and Brazil recognize the relevance to the CPMI principles (including the corporate governance principles). The Central Bank of Brazil, for example, has already informed that it utilizes CPMI's principles in the monitoring and evaluation of the safety, efficiency and integrity of the compensation and liquidation systems in the Brazilian Payment Systems, which highlights their importance ${ }^{3}$ (BCB, 2014).

\section{METHODOLOGY}

The present study is classified as a descriptive research and has a predominantly qualitative approach. Of all the countries belonging to the CPMI, payment systems operators from Brazil and the United Kingdom were selected as the object of this study. These countries were also selected for possessing data of easier access to the researchers.

Four payment systems operators were selected, two from Brazil and two from the United Kingdom, and of which two have payment systems classified as large-values and two as retail. The Frame 3 details the payment system operators and the payment systems they control, along with a brief description of each of the operators. While the Bank of Brazil operates in various financial segments, such as retail banking, the other three operators are organisations with closed capital that manage payment systems. For these three non-bank payment system operators, there are direct participants that share ownership of the operator.

3. The Central Bank of Brazil has as its one of primordial objectives to "ensure the efficiency and safety in the use of payment instruments by which currency is transferred" (BCB, 2013, p.2), and also to "ensure that the infrastructures and the arrangements operated in Brazil be managed consistently with the objectives of public interest, maintaining the financial stability and reducing system risk" (BCB, 2013, p.6). 
Frame 3 - Payment systems operators selected to participate in the study.

\begin{tabular}{|c|c|c|c|c|}
\hline \multirow{2}{*}{ COUNTRY } & \multicolumn{2}{|r|}{ PAYMENT SYSTEM OPERATOR } & \multicolumn{2}{|c|}{ PAYMENT SYSTEM } \\
\hline & NAME & DESCRIPTION & NAME & CLASS \\
\hline \multirow[b]{2}{*}{ Brazil } & CIP & $\begin{array}{l}\text { Founded in } 2001 \text { initially by the name } \\
\text { Clearingban, it is a non-profit organisation with } \\
\text { closed capital that operates, among others, the } \\
\text { payment system called SITRAF. }\end{array}$ & SITRAF & $\begin{array}{l}\text { Large value } \\
\text { payment } \\
\text { system }\end{array}$ \\
\hline & $\begin{array}{c}\text { Bank of Brazil } \\
\text { S.A. }\end{array}$ & $\begin{array}{l}\text { The Bank of Brazil is the biggest in Latin America } \\
\text { by assets. The bank is a listed company since } \\
\text { 1977, and adopts the additional corporate } \\
\text { governance practices agreed with the Brazilian } \\
\text { stock exchange - BM\&FBOVESPA. The Brazilian } \\
\text { federal government is the major shareholder } \\
\text { with } 57.9 \% \text { of stocks, as of June 2015. The } \\
\text { Bank of Brazil operates the COMPE, a cheque } \\
\text { compensation system. }\end{array}$ & COMPE & $\begin{array}{l}\text { Retail } \\
\text { payment } \\
\text { system }\end{array}$ \\
\hline \multirow{2}{*}{$\begin{array}{l}\text { United } \\
\text { Kingdom }\end{array}$} & CHAPS Co. & $\begin{array}{l}\text { It is a closed capital company founded in } 1984 \text {. } \\
\text { It operates the payment system called CHAPS. } \\
\text { The payment system has } 22 \text { direct participants, } \\
\text { whom are also owners, and more than 5,000 } \\
\text { indirect participants. }\end{array}$ & CHAPS & $\begin{array}{l}\text { Large value } \\
\text { payment } \\
\text { system }\end{array}$ \\
\hline & C\&CCC & $\begin{array}{l}\text { Founded in 1985, the company is responsible } \\
\text { for the compensation of cheques in the United } \\
\text { Kingdom since 1996. It is a non-profit closed } \\
\text { capital organisation, which the owners are also } \\
\text { participants of the payment system C\&CC. }\end{array}$ & C\&CC & $\begin{array}{l}\text { Retail } \\
\text { payment } \\
\text { system }\end{array}$ \\
\hline
\end{tabular}

Source: Adapted from CPSS (2011), CIP (2015) and research data.

Legend: 'CLASS' - Classification; 'SITRAF' - Funds Transfer System; 'CHAPS' - Clearing House Automated Payment System; 'COMPE' - Cheque Compensation Centralizer; 'C\&CC' - Cheque \& Credit Clearings; 'CIP' - Interbanking Payment Chamber; 'C\&CCC' - Cheque \& Credit Clearing Company. 
Data was collected from public documents from the aforementioned payment system operators such as articles of association, bylaws and annual reports. These documents were collected via internet between 1st Aug 2015 and 31st Aug 2015. As mentioned at introduction, to measure the presence and absence of corporate governance characteristics of each payment system operator documents, we employed content analysis (BARDIN, 1977) according to checklist composed of 20 key elements aggregated in 7 key considerations, as shown in the Frame 2 of Section 2.2. In complement of the content analysis, this study employed the binomial statistical non parametric tests, as shown in Siegel and Castellan (2006). Lastly, the software SPSS 22.0 was used to subsidise the analysis, detailed in Section 4.

\section{RESULTS AND DISCUSSION}

The Frame 4 lists the results of analysis of corporate governance characteristics by key elements. The 20 key elements were initially presented in the Frame 2 of the Section 2.2. Each key element has been attributed with a present or absent classification for each operator. The last column describes the total percentage present for each key element.

Of the twenty key elements studied and shown in the Frame 4, nine exhibited a degree of $100 \%$ of presence, while 2 exhibited a $0 \%$ degree: key element 11 (Identification of the appropriate skill sets for board members) and key element 17 (Identification of board processes to determine, endorse, and regularly review the risk-management framework).

The key element 3 (Explicit support for financial stability and other relevant public interests in the FMI's objectives) was present only for CHAPS Co. In its objectives, CHAPS (2014, p. 5) states that: "To this end, the Company, as a critical financial market infrastructure, and its Board of Directors are responsible for ensuring the mitigation and managing of systemic risk". 
Frame 4 - Analysis by key element.

\begin{tabular}{|c|c|c|c|c|c|c|c|}
\hline KEY ELEMENT & CIP & BANK OF BRAZIL & CHAPS & C\&CCC & $\begin{array}{c}\text { PRESENT } \\
\text { TOTAL }\end{array}$ & $\begin{array}{c}\text { ABSENT } \\
\text { TOTAL }\end{array}$ & PRESENT \% \\
\hline 1 & $P$ & $P$ & $P$ & $P$ & 4 & 0 & $100.00 \%$ \\
\hline 2 & $A$ & $A$ & $A$ & $P$ & 1 & 3 & $25.00 \%$ \\
\hline 3 & $A$ & $A$ & $P$ & A & 1 & 3 & $25.00 \%$ \\
\hline 4 & $P$ & $P$ & $P$ & $P$ & 4 & 0 & $100.00 \%$ \\
\hline 5 & $\mathrm{P}$ & $\mathrm{P}$ & $\mathrm{P}$ & $P$ & 4 & 0 & $100.00 \%$ \\
\hline 6 & $P$ & $P$ & $P$ & $P$ & 4 & 0 & $100.00 \%$ \\
\hline 7 & $P$ & $P$ & $P$ & $P$ & 4 & 0 & $100.00 \%$ \\
\hline 8 & $P$ & $P$ & $P$ & $P$ & 4 & 0 & $100.00 \%$ \\
\hline 9 & $P$ & $P$ & $P$ & $P$ & 4 & 0 & $100.00 \%$ \\
\hline 10 & A & $P$ & A & A & 1 & 3 & $25.00 \%$ \\
\hline 11 & A & A & A & A & 0 & 4 & $0.00 \%$ \\
\hline 12 & $A$ & A & $\mathrm{P}$ & $P$ & 2 & 2 & $50.00 \%$ \\
\hline 13 & $A$ & $\mathrm{P}$ & $\mathrm{P}$ & $P$ & 3 & 1 & $75.00 \%$ \\
\hline 14 & $P$ & $P$ & A & A & 2 & 2 & $50.00 \%$ \\
\hline 15 & $A$ & $P$ & A & $A$ & 1 & 3 & $25.00 \%$ \\
\hline 16 & $P$ & $P$ & $P$ & $P$ & 4 & 0 & $100.00 \%$ \\
\hline 17 & $A$ & A & A & A & 0 & 4 & $0.00 \%$ \\
\hline 18 & $P$ & $P$ & $A$ & A & 2 & 2 & $50.00 \%$ \\
\hline 19 & $\mathrm{P}$ & A & $P$ & $P$ & 3 & 1 & $75.00 \%$ \\
\hline 20 & $P$ & $P$ & $P$ & $P$ & 4 & 0 & $100.00 \%$ \\
\hline
\end{tabular}

Source: Research data.

Legend: P) Present; A) Absent; Key Element - 1) Identification of the FMI's objectives; 2) Prioritisation of safety and efficiency in the FMI's objectives; 3) Explicit support for financial stability and other relevant public interests in the FMI's objectives; 4) Identification of the governance arrangements under which the board and management operate; 5) Identification of lines of responsibilities and accountability within the FMI; 6) Disclosure of the identified governance arrangements; 7) Identification of the roles and responsibilities of the FMI's board of directors (or equivalent); 8) Identification of procedures for the functioning of the board; 9) Identification of processes to identify, address, and manage conflicts of interest of members; 10) Review of board's performance; 11) Identification of the appropriate skill sets for board members; 12) Identification of appropriate incentives for board members; 13) Inclusion of non-executive board members; 14) Identification of the roles and responsibilities of the FMI's management; 15) Identification of skills, experience and integrity of management; 16) Identification of the risk-management framework established by the board; 17) Identification of board processes to determine, endorse, and regularly review the risk-management framework; 18) Identification of authority, independence, resources, and access to the board of the risk-management and internal control functions in governance arrangements; 19) Identification of how the legitimate interests of direct and indirect participants and other relevant stakeholders are reflected in the FMI's design, rules, strategy, and major decisions; 20) Identification of how the FMI discloses major decisions to relevant stakeholders and, where appropriate, the public. 
The key element 10 (Review of board's performance) is present only in the Bank of Brazil, in article 23 of its bylaws. The document explicitly states that the Board must annually formally review its performance, following the procedures established in the Board's bylaws and conducted by its president (BANK OF BRAZIL, 2015b).

The Key element 13 (Inclusion of non-executive board members) is also worth mentioning. The inclusion of non-executive board members is established in $75 \%$ of the operators. The Bank of Brazil (2015b) requires at least $20 \%$ of its board members as so, CHAPS (2014) establishes a minimum of 3 members and C\&CCC (2014) 2 members.

The Bank of Brazil (2015b) was also the only one in which the key element 15 (Identification of skills, experience and integrity of management) was observed as present, as its bylaws explicitly state the necessary requirements for its managers, such as possessing at least five years of experience in management roles in institutions of the financial system.

Lastly, key element 20 (Identification of how the FMI discloses major decisions to relevant stakeholders and, where appropriate, the public) was presented in $100 \%$ of the operators. The Bank of Brazil (2015b) publishes to the public quarterly performance reports and hosts annual meetings with investors and market analysts.

The Table 1 groups the analysis by key considerations. Their descriptions were presented in Frame 2 of the Section 2.2. The Table 1 indicates the amount of present key elements by operator in each of the key considerations, grouped from the results shown in the Frame 4, and their respective percentages for each operator. 
Table 1 - Analysis by key consideration.

\begin{tabular}{|c|c|c|c|c|}
\hline KEY CONSIDERATION & CIP & BANK OF BRAZIL & CHAPS & C\&CCC \\
\hline 1 -Objectives & $\begin{array}{c}1 \\
(33.33 \%)\end{array}$ & $\begin{array}{c}1 \\
(33.33 \%)\end{array}$ & $\begin{array}{c}2 \\
(66.67 \%)\end{array}$ & $\begin{array}{c}2 \\
(66.67 \%)\end{array}$ \\
\hline $\begin{array}{l}\text { 2- Lines of responsibility } \\
\text { and accountability }\end{array}$ & $\begin{array}{c}3 \\
(100.00 \%)\end{array}$ & $\begin{array}{c}3 \\
(100.00 \%)\end{array}$ & $\begin{array}{c}3 \\
(100.00 \%)\end{array}$ & $\begin{array}{c}3 \\
(100.00 \%)\end{array}$ \\
\hline 3 - Board of directors & $\begin{array}{c}3 \\
(75.00 \%)\end{array}$ & $\begin{array}{c}4 \\
(100.00 \%)\end{array}$ & $\begin{array}{c}3 \\
(75.00 \%)\end{array}$ & $\begin{array}{c}3 \\
(75.00 \%)\end{array}$ \\
\hline 4 - Directors & $\begin{array}{c}0 \\
(0.00 \%)\end{array}$ & $\begin{array}{c}1 \\
(33.00 \%)\end{array}$ & $\begin{array}{c}2 \\
(66.67 \%)\end{array}$ & $\begin{array}{c}2 \\
(66.67 \%)\end{array}$ \\
\hline 5 - Management & $\begin{array}{c}1 \\
(50.00 \%)\end{array}$ & $\begin{array}{c}2 \\
(100.00 \%)\end{array}$ & $\begin{array}{c}0 \\
(0.00 \%)\end{array}$ & $\begin{array}{c}0 \\
(0.00 \%)\end{array}$ \\
\hline 6 - Risk management & $\begin{array}{c}2 \\
(66.67 \%)\end{array}$ & $\begin{array}{c}2 \\
(66.67 \%)\end{array}$ & $\begin{array}{c}1 \\
(33.37 \%)\end{array}$ & $\begin{array}{c}1 \\
(33.37 \%)\end{array}$ \\
\hline 7 -Stakeholders & $\begin{array}{c}2 \\
(100.00 \%)\end{array}$ & $\begin{array}{c}1 \\
(50.00 \%)\end{array}$ & $(100.00 \%)$ & $\begin{array}{c}2 \\
(100.00 \%)\end{array}$ \\
\hline
\end{tabular}

Source: Research data.

The results in Table 1 show that the key elements contained in the key consideration 3 (Board of directors) were present in 100\% for Bank of Brazil, while the other three had $75 \%$ of the total possible key elements. No key elements were present in CIP for the key consideration 4 (Directors). For key consideration 5 (Management), also only Bank of Brazil had a degree of $100 \%$ present. CHAPS and C\&CCC had a degree of $0 \%$ for this key consideration. Three of the four operators had all of the key elements present in key consideration 7 (Stakeholders).

With the data obtained in Table 1, the binomial statistic test was performed and its results are shown in the Table 2 . The test indicates if the distribution of present and absent elements in each key consideration is the expected from a binomial distribution of two factors, in which the probability of each occurring is equal, 50\%. This is null hypothesis. Table 2 enumerates the total of key elements present and absent in each key consideration along with their respective percentage degrees, presents the result of the binomial statistic test and indicates whether the test has rejected or not the null hypothesis for each of the key considerations. 
Table 2 - Analysis by key consideration and binomial statistical test results.

\begin{tabular}{|c|c|c|c|c|}
\hline $\begin{array}{c}\text { KEY } \\
\text { CONSIDERATION }\end{array}$ & $\begin{array}{l}\text { PRESENT } \\
\text { ELEMENTS }\end{array}$ & $\begin{array}{c}\text { ABSENT } \\
\text { ELEMENTS }\end{array}$ & SIGNIFICANCE & DECISION \\
\hline 1 - Objectives & $\begin{array}{c}6 \\
(50.00 \%)\end{array}$ & $\begin{array}{c}6 \\
(50.00 \%)\end{array}$ & 1.00 & $\begin{array}{l}\text { Does not reject the } \\
\text { null hypothesis }\end{array}$ \\
\hline $\begin{array}{l}2 \text { - Lines of responsibility } \\
\text { and accountability }\end{array}$ & $\begin{array}{c}12 \\
(100.00 \%)\end{array}$ & $\begin{array}{c}0 \\
(0.00 \%)\end{array}$ & $0.00^{* *}$ & $\begin{array}{l}\text { Rejects the null } \\
\text { hypothesis }\end{array}$ \\
\hline 3 - Board of directors & $\begin{array}{c}13 \\
(81.25 \%)\end{array}$ & $\begin{array}{c}3 \\
(18.75 \%)\end{array}$ & $0.02^{* *}$ & $\begin{array}{l}\text { Rejects the null } \\
\text { hypothesis }\end{array}$ \\
\hline 4 - Directors & $\begin{array}{c}5 \\
(41.67 \%)\end{array}$ & $\begin{array}{c}7 \\
(58.33 \%)\end{array}$ & 0.77 & $\begin{array}{c}\text { Does not reject the } \\
\text { null hypothesis }\end{array}$ \\
\hline 5 -Management & $\begin{array}{c}3 \\
(37.50 \%)\end{array}$ & $\begin{array}{c}5 \\
(62.50 \%)\end{array}$ & 0.72 & $\begin{array}{c}\text { Does not reject the } \\
\text { null hypothesis }\end{array}$ \\
\hline 6 - Risk management & $\begin{array}{c}6 \\
(50.00 \%)\end{array}$ & $\begin{array}{c}6 \\
(50.00 \%)\end{array}$ & 1.00 & $\begin{array}{l}\text { Does not reject the } \\
\text { null hypothesis }\end{array}$ \\
\hline 7 -Stakeholders & $\begin{array}{c}7 \\
(87.50 \%)\end{array}$ & $\begin{array}{c}1 \\
(12.50 \%)\end{array}$ & $0.07^{*}$ & $\begin{array}{l}\text { Does not reject the } \\
\text { null hypothesis }\end{array}$ \\
\hline
\end{tabular}

Source: Research data.

** Significance Level of 0,05 .

* Significance Level of 0,10.

While analysing the percentages of key elements present and absent by key consideration, according to Table 2, it is noted that the key consideration 2 (Lines of responsibility and accountability) had shown a degree of presence of $100 \%$, while key consideration 5 (Management) had a 37.5\%. The key consideration 7 (Stakeholders) had a degree of presence of $87.5 \%$, with only a single element absent. In the case of CHAPS (2014), the direct participants are the owners of the company, and any resolution for the board of directors that might be of public interest has to be approved by the majority of the independent directors. 
As for the binomial statistical test, cited in Table 2, what can be observed is that for a significance level of 0.05 , the key considerations 2 (Lines of responsibility and accountability) and 3 (Board of directors) the null hypothesis was rejected, which means that the distribution of present and absent key elements in each of these key considerations cannot be considered as a distribution with a $50 \%$ chance of occurring each possibility. The other five key considerations did not show results which would allow the test to reject the null hypothesis. If the considered significance level is 0.10 , key consideration 7 (Stakeholders) will also have the null hypothesis rejected by the test.

\section{CONCLUSIONS}

The main objective of this study is to investigate the corporate governance characteristics of payment systems operators in Brazil and the United Kingdom, based on recommendations of the CPMI. This research differs of others because it employs principles and recommendations about corporate governance to allow data comparability of payment system operators in an international framework. Additionally, it can bring corporate governance insights to academics and others stakeholders involved in the improvement of operation, regulation and supervision of payment systems, mainly in Brazil and the United Kingdom.

A descriptive study was done, with a qualitative approach, covering both bibliographical and documental research. We analysed bylaws and others documents of four payment systems operators intentionally selected from Brazil and the United Kingdom. To measure the presence and absence of corporate governance characteristics of each payment system operator, we employed content analysis, considering a checklist composed of 20 key elements distributed in 7 key considerations based on aforementioned international recommendations for corporate governance of the CPMI. We also employed the binomial tests in the data analysis.

The main results about the analysis of corporate governance characteristics based on 80 key elements show that, in general, $65 \%$ of the key elements are present in the payment systems operators' documents analysed. However, this percentage was not distributed uniformly. Two key considerations presented a statistically predominant percentage of key elements present: 'Lines of responsibility and accountability' (100\% of key elements presents) and 'board of directors', respectively (75\% of key elements presents). 
This study limits itself to describe the information presented by the operators, in documents and bylaws, via their internet websites in August 2015. As suggestions for future studies, research can be done by investigating the corporate governance characteristics of payment system operators as per the CPMI's recommendation considering other operators from Brazil and United Kingdom, or even other countries. Another suggestion is to analyse different time periods, such as soon after the 2008 subprime crisis, with an objective to investigate if there have been structural differences in corporate governance characteristics of payment system operators. Finally, other characteristics can also be investigated for other applicable principles of the CPMI, aside from corporate governance, for payment systems.

\section{REFERENCES}

ANDRADE, A.; ROSSETTI, J. P. Corporate Governance: Foundations, Development and Trends. Sao Paulo: Atlas publishing company, 2004.

BANK OF BRAZIL. New Market Requirements. Brasilia: Bank of Brazil, 2015a. Available at: <http://www.bb.com.br/portalbb/portalbb/page3,136,3494,0,0,1,8. bb? codigoNoticia $=651 \&$ codigoMenu $=203 \&$ codigoRet $=835 \&$ bread $=18 \_2>$. Retrieved 31 October 2015.

Bylaws. Brasilia: Bank of Brazil, 2015b. Available at: <http://www. bb.com.br/ portalbb/page3,136,3508,0,0,1,8.bb?codigoMenu=203\&codigoNotici $\mathrm{a}=669 \&$ codigoRet $=824 \&$ bread $=5>$. Retrieved 02 August 2015 .

BARDIN, L. Content Analysis. Lisboa publishing company: 70 editions, 1977.

BCB.BrazilianCentralBank.Bulletinn'25.097, January10th.Brasilia:Department of Banking operations and Payment Systems, 2014. Available at: $<$ https://www3. bcb.gov.br/normativo/detalharNormativo.do?method=detalharNormativo\& $\mathrm{N}=114001893>$. Retrieved 01 October 2015.

. Brazilian Payment System Surveillance report. Brasilia: Department of Investor relationship and special studies, 2013. Available at: <http://www. bcb.gov.br/htms/ novaPaginaSPB/RELATORIO_DE_VIGILANCIA_SPB2013. pdf>. Retrieved 16 May 2015. 
BICG. Brazilian Institute For Corporate Governance. Code of Best Practices for Corporate Governance. Sao Paulo: IBGC, 2009. Available at: <http://www. ibgc. org.br/userfiles/ files/Codigo_Final_4a_Edicao.pdf>. Retrieved 29 May 2015.

BIS. Bank for International Settlements. About the CPMI. Updated 10 February 2016. Available at: < http://www.bis. org/cpmi/info.htm?m=3\%7C16\%7C29>. Retrieved 24 December 2016.

C\&CCC. Credit and Cheque Clearing Company. Articles of Association of Cheque and Credit Clearing Company Limited. London: C\&CCC, 2014. Available at: <http://www.chequeandcredit.co.uk/files/candc/c\&ccc/pdf_and_docs/ articles_of_association_(05june15).pdf $>$. Retrieved 08 August 2015.

CHAPS. Chaps Clearing Company Limited. Articles of Association of Chaps Clearing Company Limited. London: Chaps, 2014. Available at: <http://www. chapsco.co.uk/files/ chaps/governance_documents/ memorandum_ and_articles_of_association.pdf $>$ Retrieved 08 August 2015.

CIP. Interbanking Payment Chamber. Bylaws of the Interbanking Payment Chamber. Sao Paulo: CIP - Public, 2015. Available at: <https://www.cip-bancos. org.br/dms/cip/ Governanca/Estatuto-Social/Estatuto Social.pdf $>$. Retrieved 15 August 2015.

CPMI. Committee on Payments and Market Infrastructures. Charter. Bank for International Settlements, September, 2014a. Available at: <http://www.bis.org/ cpmi/charter.pdf>. Retrieved 03 May 2015.

Statistics on payment, clearing and settlement systems in the CPMI countries. Figures for 2013. Bank for International Settlements, December, 2014b. Available at: <http://www.bis.org/cpmi/publ/d124.pdf >. Retrieved 14 Abril 2015.

CPSS. Committee on Payment and Settlement Systems. Core Principles for Systematically Important Payment Systems. Bank for International Settlements, January, 2001. Available at: <http://www.bis.org/cpmi/publ/d43. pdf $>$. Retrieved 15 April 2015. 
Payment, clearing and settlement systems in the CPSS countries. Bank for International Settlements, September, 2011. Available at: $<$ http://www. bis.org/cpmi/publ/d97. pdf>. Retrieved 16 May 2015.

CPSS-IOSCO. Committee on Payment and Settlement Systems and Technical Committee of the International Organization of Securities Commissions. Principles for financial market infrastructures. Bank for International Settlements, April, 2012a. Available at: <http://www.bis.org/cpmi/publ/d101a.pdf $>$. Retrieved 03 May 2015.

Disclosure framework for financial market infrastructures. Bank for International Settlements, April, 2012b. Available at: <http://www.bis.org/ cpmi/publ/d101c. pdf>. Retrieved 07 May 2015.

OECD. Organisation for Economic Co-operation and Development (OECD). G20/OECD Principles of Corporate Governance. Ankaar: Head of Publication Services, 2015. Available at: <http://www.oecd.org/daf/ca/Corporate-Governance-Principles-ENG.pdf $>$. Retrieved 14 November 2015.

OLIVEIRA, D. P. R. Corporate Governance in Practice: Integrating shareholders, Board of Directors and Executive Directors in generating results. Sao Paulo: Atlas Publishing S.A., 2015.

SIEGEL, S.; CASTELLAN JR, J. N. Nonparametric Statistics for the Behavioural Sciences. Porto Alegre: Artmed, 2006. 